\title{
PEMBELAJARAN MATEMATIKA REALISTIK PADA MATERI PENJUMLAHAN DAN PENGURANGAN BILANGAN BULAT BAGI SISWA KELAS IV SEKOLAH DASAR
}

\author{
Rissa Prima Kurniawati \\ Prodi PGSD FIP IKIP PGRI MADIUN
}

\begin{abstract}
Mathematics has characteristic in good abstract object. That cause students have difficulty in understanding of mathematics. Therefore, the real-life experiences of children in the classroom are important for learning and students will understand the material quickly. This study is aimed to describe the activities of students during the learning process that takes place in the material realistic arithmetic addition and subtraction and describe the learning completeness students after being taught with realistic learning the material arithmetic addition and subtraction of integers. This type of research used in this research is qualitative research. Subjects in this study were students of class IV SDN Jenangan, Kwadungan, Ngawi.Based on this research, student activities relevant to teaching (teaching and learning) of $98.83 \%$ classified in the category very well. While the student activity which is not relevant to the teaching of $10.15 \%$. Completeness students in realistic mathematics learning on the material arithmetic operations of addition and subtraction of integers for fourth grade students of SDN Jenangan, Kwadungan, Ngawi gained mastery learning students individually sebannyak 12 students from the number of students as many as 15 students altogether, which is not completed individually as 3 students. While the classical completeness, acquired $80 \%$ of students who completed study.
\end{abstract}

Keywords: Learning, Realistic Mathematics

\begin{abstract}
Abstrak
Matematika memiliki karakteristik, yaitu mempunyai objek yang bersifat abstrak. sifat matematika yang abstrak ini menyebabkan siswa mengalami kesulitan dalam memahami matematika. Oleh karena itu, pengalaman kehidupan nyata anak dalam pembelajaran di kelas itu penting dilakukan agar pembelajaran lebih bermakna dan siswa cepat memahami materi. Penelitian ini bertujuan untuk mendeskripsikan aktivitas siswa selama proses pembelajaran realistik berlangsung pada materi hitung penjumlahan dan pengurangan bilangan bulat dan mendeskripsikan ketuntasan belajar siswa setelah diajar dengan pembelajaran realistik pada materi penjumlahan dan pengurangan bilangan bulat. Jenis penelitian yang digunakan dalam penelitian ini adalah penelitian kualitatif. Subyek pada penelitian ini adalah siswa kelas IV SDN Jenangan, Kwadungan, Ngawi. Berdasarkan hasil penelitian, aktivitas siswa yang relevan dengan KBM (kegiatan belajar mengajar) sebesar 98,83\% tergolong dalam kategori sangat baik. Sedangkan aktivitas siswa yang tidak relevan dengan KBM sebesar 10,15\%. Ketuntasan siswa dalam pembelajaran matematika realistik pada materi operasi hitung penjumlahan dan pengurangan bilangan bulat bagi siswa kelas IV SDN Jenangan, Kwadungan, Ngawi diperoleh ketuntasan belajar siswa secara individu sebanyak 12 orang siswa dari jumlah siswa seluruhnya yaitu 15 orang siswa, yang tidak tuntas secara individu sebanyak 3 orang siswa. Sedangkan ketuntasan klasikal diperoleh $80 \%$ dari siswa yang tuntas belajar.
\end{abstract}

Kata Kunci: Pembelajaran, Matematika Realistik 


\section{A. Pendahuluan}

Salah satu proses pembelajaran yang mengedepankan daya nalar dari peserta didik adalah matematika. Matematika merupakan disiplin ilmu yang dibutuhkan oleh berbagai ilmu pengetahuan lainnya, karena matematika adalah suatu cara berpikir yang jelas dan tepat sebagai sarana pengembangan ilmu pengetahuan dan teknologi. Matematika merupakan alat yang efisien untuk membantu ilmu pengetahuan. Matematika memiliki karakteristik, yaitu mempunyai objek yang bersifat abstrak. Sehingga sifat matematika yang abstrak ini menyebabkan siswa mengalami kesulitan dalam memahami matematika.

Matematika dipelajari
hampir di setiap jenjang
pendidikan. Ini merupakan wujud
dari pengakuan bahwa matematika
sangat dibutuhkan dalam
pengembangan pengetahuan dan
kehidupan sehari-hari. Sekolah
merupakan salah satu lembaga
yang memberikan kesempatan
pada siswa untuk mempelajarinya,
menghargai dan memperoleh nilai,
tetapi banyak permasalahan-
permasalahan yang menghambat
siswa berhasil melakukan hal-hal
tersebut. Hal ini tentunya tidak
terlepas dari bagaimana seorang
guru menggunakan strategi
mengajar yang baik, serta
memperhatikan pendekatan

mengajar yang sesuai dengan keadaan siswa, bukan pendekatan mengajar yang bersifat monoton serta kurang bervariasi, karena hal ini dapat membuat siswa kurang motivasi atau keinginan untuk mempelajari matematika. Untuk mengatasi masalah tersebut, perlu diteliti suatu pendekatan lain dalam pembelajaran matematika yang memungkinkan siswa dapat mengoptimalkan kemampuannya. Setyosari (dalam Arindawati \& Huda, 2004:39) menyatakan bahwa Pembelajaran merupakan suatu usaha manusia yang dilakukan dengan tujuan untuk membantu memfasilitasi belajar orang lain. Secara khusus, pembelajaran merupakan upaya yang dilakukan oleh guru untuk membantu siswa agar dapat belajar dengan mudah.

Guru sebagai pendidik harus menyadari bahwa kemajuan pendidikan lebih tergantung pada dedikasi guru serta kreativitasnya. Oleh karena itu rendahnya pembelajaran matematika disekolah sangat ditentukan oleh guru, karena guru sebagai ujung tombak kegiatan pembelajaran dikelas. Kondisi ini disebabkan belum efektifnya penggunaan strategi, pendekatan mengajar, dan lemahnya kemampuan guru matematika SD dalam menguasai materi pelajaran tertentu. Kebanyakan siswa mengalami kesulitan dalam mengaplikasikan matematika ke dalam situasi kehidupan real. Hal lain yang menyebabkan sulitnya matematika bagi siswa adalah karena pembelajaran matematika kurang bermakna. Guru dalam pembelajarannya di kelas belum mengaitkan dengan skema 
yang telah dimiliki oleh siswa dan siswa kurang diberikan kesempatan untuk menemukan kembali serta mengonstruksi sendiri ide-ide matematika. Mengaitkan pengalaman kehidupan nyata anak dengan ide-ide matematika dalam pembelajaran di kelas penting dilakukan agar pembelajaran lebih bermakna. Bila anak belajar matematika terpisah dari pengalaman mereka sehari-hari maka anak akan cepat lupa dan tidak dapat mengaplikasikan matematika (Suharta, 2001).

Pembelajaran matematika di kelas ditekankan pada keterkaitan antara konsep-konsep matematika dengan pengalaman anak sehari-hari. Selain itu, perlu menerapkan kembali konsep matematika yang telah dimiliki anak pada kehidupan sehari-hari atau pada bidang lain sangat penting dilakukan. Salah satu pembelajaran matematika yang berorientasi pada pengalaman sehari-hari (mathematize of everyday experience) dan menerapkan matematika dalam kehidupan sehari-hari adalah pembelajaran Matematika Realistik (MR). Pendekatan Matematika Realistik (PMR) atau Realistic Mathematics Education (RME) merupakan konsep belajar yang membantu guru mengaitkan antara materi yang diajarkannya dengan situasi dunia nyata siswa dan mendorong siswa membuat hubungan antara pengetahuan yang dimilikinya dengan penerapannya dalam kehidupan mereka sebagai anggota keluarga dan masyarakat.

Menurut Hauvel-Panhuizen (Inganah 2003:12) Realistic Mathematics Education (RME) merupakan suatu pembelajaran yang menggunakan masalah kontekstual dan situasi kehidupan nyata untuk memperoleh dan mengaplikasikan konsep matematika. Konsep RME menurut Freudenthal yang berkaitan dengan pembelajaran matematika (Suryanto, 2007:8) adalah:

1. Matematisasi, artinya bahwa ilmu tidak lagi hanya sekedar kumpulan pengalaman, ilmu melibatkan kegiatan mengorganisasi pengalaman dengan menggunakan matematika yang disebut mathematizing (matematisasi atau mematematikakan). Matematisasi terdiri dari dua tipe yaitu matematika vertikal dan matematika horizontal. Matematisasi horizontal berkaitan dengan pengetahuan yang telah dimiliki siswa sebelumnya bersama intuisi mereka sebagai alat untuk menyelesaikan masalah dari dunia nyata. Sedangkan Matematisasi vertikal berkaitan dengan proses organisasi kembali pengetahuan yang telah diperoleh dalam simbol-simbol matematika yang lebih abstrak.

2. Matematika sebagai produk jadi dan matematika sebagai kegiatan. Pembelajaran yang berdasarkan paham bahwa matematika harus diajarkan sebagai barang jadi atau sebagai sistem deduktif, menghasilkan pandangan bahwa matematika tidak 
berguna, karena pembelajaran matematika hanya berisi kegiatan menghafalkan aksioma, definisi, terima serta penerapan pada soal-soal.

3. Kegiatan atau aktivitas. Pengetahuan dan kecakapan yang diperoleh dengan cara penemuan akan lebih dipahami dan lebih awet dalam ingatan daripada pengetahuan atau kecakapan yang diperoleh dengan cara pasif.

4. Re-invention atau penemuan, artinya bahwa kegiatan

pembelajaran matematika harus berdasarkan pada penafsiran dan analisis matematika.

Langkah-langkah dalam pembelajaran menggunakan Model RME yaitu diawali dengan matematisasi. Langkah matematisasi menurut Wijaya (2011) yaitu: (1) permasalahan diawali dengan dunia nyata, (2) mengidentifikasi konsep mate matika yang relevan dengan masa lalu peserta didik dan mengorganisasikan masalah sesuai dengan konsep matematika, (3) kemudian secara bertahap, meninggal-kan situasi dunia nyata melalui proses perumusan asumsi, generalisasi dan for-malisasi. Proses tersebut bertujuan untuk menterjemahkan masalah dunia nyata kedalam masalah matematika yang repre-sentatif, menyelesaikan masalah matematika, dan (5) menerjemahkan kembali solusi matematis kedalam situasi nyata, termasuk mengidentifikasi keterbatasan dari solusi. terlebih dahulu diungkapkan.

Pada pendekatan realistik, pembelajaran matematika lebih ditekankan pada aktivitas, yaitu aktivitas matematika. Sedangkan dalam proses implementasi dikelas, pembelajaran matematika realistik menggunakan lima karakteristik dasar adalah menggunakan masalah kontekstual, menggunakan model atau jembatan, menggunakan kontribusi siswa, mengunakan interaktif, dan menggunakan keterkaitan (Treffers dalam Ruseffendi, 2010).

Dengan konsep itu hasil pembelajaran diharapkan lebih bermakna bagi siswa. Berdasarkan uraian diatas maka perlu diadakan suatu penelitian tentang pembelajaran matematika realistik pada materi penjumlahan dan pengurangan bilangan bulat bagi siswa kelas IV SDN Jenangan, Kwadungan, Ngawi. Penelitian ini bertujuan untuk mendeskripsikan aktivitas siswa kelas IV SDN Jenangan, Kwadungan, Ngawi selama proses pembelajaran realistik berlangsung pada materi penjumlahan dan pengurangan bilangan bulat dan mendeskripsikan ketuntasan belajar siswa kelas IV SDN Jenangan, Kwadungan, Ngawi setelah diajar dengan pembelajaran realistik pada materi penjumlahan dan pengurangan bilangan bulat.

\section{B. Metode Penelitian}

Pada penelitian ini, peneliti ingin mendeskripsikan tentang aktivitas siswa 
kelas IV SDN Jenangan, Kwadungan, Ngawi selama proses pembelajaran realistik berlangsung pada materi penjumlahan dan pengurangan bilangan bulat dan ketuntasan belajar siswa kelas IV SDN Jenangan, Kwadungan, Ngawi setelah diajar dengan pembelajaran matematika realistik. Oleh karena itu, jenis penelitian yang digunakan dalam penelitian ini adalah penelitian kualitatif. Moleong (2006:6) mengemukakan bahwa penelitian kualitatif merupakan penelitian yang dimaksudkan untuk memahami tentang fenomena, tentang apa yang dialami oleh subyek penelitian misalnya perilaku, persepsi, motivasi, tindakan dan lain-lain, secara holistik, dan dengan cara deskripsi dalam bentuk katakata dan bahasa, pada suatu konteks khusus yang alamiah dan dengan memanfaatkan berbagai metode ilmiah. Dalam penelitian ini peneliti yang melaksanakan, merencanakan pembelajaran, mengumpulkan data, menganalisis data, menarik kesimpulan serta membuat laporan.

Subyek dalam penelitian ini adalah siswa kelas IV SDN Jenangan, Kwadungan, Ngawi yang berjumlah 15 siswa. Data yang dikumpulkan dalam penelitian ini adalah:

1. Hasil observasi yang diperoleh dari pengamatan teman sejawat terhadap aktivitas siswa selama proses belajar mengajar dengan pembelajaran matematika realistik pada materi penjumlahan dan pengurangan bilangan bulat.

2. Hasil tes akhir siswa digunakan untuk mengetahui ketuntasan belajar siswa.

Sebelummelaksanakan

penelitian, dilakukan berbagai kegiatan observasi di lokasi penelitian. Adapun tahap-tahap yang dilaksanakan dalam penelitian ini sebagai berikut:

a) Tahap Persiapan

Sebelum melaksanakan penelitian, peneliti melakukan pertemuan awal dengan kepala sekolah tentang rencana penelitian yang dilaksanakan. Melakukan wawancara dengan guru matematika yaitu guru kelas IV SDN Jenangan tentang waktu penelitian, materi yang akan disampaikan,. Sedangkan perangkat penelitian yang akan disiapkan meliputi: 1) perangkat pembelajaran (silabus, RPP, lembar kerja siswa), 2) soal tes akhir, dan

3) lembar observasi aktivitas siswa

b) Tahap Pelaksanaan

1. Melaksanakan kegiatan pembelajaran yang telah dipersiapkan sebanyak tiga kali pertemuan yaitu pada pertemuan pertama dan kedua dilaksanakan pembelajaran matematika realistik dan pertemuan ketiga dilaksanakan tes akhir dan pengisian angket.

2. Melakukan observasi

Observasi dilakukan selama kegiatan pembelajaran berlangsung yang dilakukan oleh teman sejawat.

3. Mengadakan tes

Tes dilakukan pada akhir kegiatan pembelajaran untuk mengetahui atau mengukur ketuntasan belajar siswa. 
Sedangkan teknik pengumpulan data dalam penelitian ini adalah:

1. Observasi (pengamatan) Observasi ini dilaksanakan untuk mengamati aktivitas siswa selama proses pembelajaran berlangsung. Pengamatan dilakukan oleh teman sejawat dengan mengisi lembar observasi aktivitas siswa yang telah disediakan.

2. Tes

Tes digunakan untuk mengetahui ketuntasan belajar setiap siswa dan ketuntasan satu kelas (ketuntasan klasikal). Tes prestasi belajar digunakan untuk mengetahui sejauh mana ketuntasan balajar siswa di dalam kelas setelah menggunakan pembelajaran matematika realistik. Tes ini diberikan pada akhir pembelajaran.

\section{Hasil Penelitian}

1. Aktivitas Siswa dalam Kegiatan Pembelajaran

Berdasarkan data yang diperoleh dari hasil pengamatan yang dilakukan oleh pengamat selama pembelajaran berlangsung yaitu pada pertemuan I dan pertemuan II, pengamatan dilakukan pada 8 orang siswa dan hasil pengamatan ditulis dalam lembar pengamatan. Hasil pengamatan terhadap 8 siswa disajikan pada Tabel 1.

\section{Tabel 1. Aktivitas Siswa dalam Kegiatan Pembelajaran}

\begin{tabular}{lccc}
\hline \multirow{2}{*}{ Kategori Pengamatan Aktivitas Siswa } & \multicolumn{2}{c}{ Presentasi Aktivitas Siswa } & \multirow{2}{*}{\begin{tabular}{c} 
Rata- \\
\cline { 2 - 3 }
\end{tabular}} \\
\cline { 2 - 3 } rata (\%) \\
\cline { 2 - 3 } 1. Memperhatikan penjelasan guru & 1 & 2 & \\
\hline 2. Membentuk Kelompok & 6,25 & 6,25 & 6,25 \\
\hline $\begin{array}{l}\text { 3. Berdiskusi/ menganalisis permasalahan } \\
\text { melalui LKS }\end{array}$ & 22,66 & 25 & 23,83 \\
\hline $\begin{array}{l}\text { 4. Mengemukakan pendapat/bertanya antar } \\
\text { siswa atau guru }\end{array}$ & 18,75 & 19,53 & 19,14 \\
\hline 5. Membaca buku dan menulis & 20,31 & 21,87 & 21,09 \\
\hline 6. Mempresentasikan hasil diskusi & 11,72 & 11,72 & 11,72 \\
\hline 7. Perilaku yang tidak relevan dengan KBM & 10,94 & 9,37 & 10,15 \\
\hline
\end{tabular}

Hasil pengamatan aktivitas siswa pada tabel di atas dapat diketahui bahwa kategori (1) memperhatikan penjelasan guru sebesar 16,8\%, (2) membentuk kelompok sebesar 6,25\%, Berdiskusi/ Menganalisis permasalahan melalui LKS sebesar 23,83 $\%$ (4) mengemukakan pendapat/bertanya antar siswa atau guru sebesar 19,14\%, (5) Membaca buku dan menulis 21,09\%, (6) Mempresentasikan hasil diskusi sebesar $25,39 \%$, (7) perilaku yang tidak relevan dengan KBM diperoleh 10,15\%. 
Jumlah rata-rata aktivitas siswa yang relevan dengan KBM (kegiatan belajar mengajar) secara keseluruhan selama diterapkan pembelajaran matematika realistik pada materi penjumlahan dan pengurangan bilangan bulat bagi siswa kelas IV SDN Jenangan yaitu sebesar 98,83\%. Sedangkan aktivitas siswa yang tidak relevan dengan KBM sebesar 10,15\%. Hal ini menunjukan bahwa aktivitas siswa yang relevan dengan KBM lebih baik dari pada aktivitas siswa yang tidak relevan dengan KBM.

\section{Ketuntasan Belajar Siswa Dengan Menggunakan Pembelajaran Matematika Realistik}

Data ini berupa skor tes. Skor tes tersebut dianalisis ketuntasan belajarnya, baik individu maupun klasikal seperti yang disajikan pada tabel 2 .

Tabel 2. Ketuntasan Siswa

\begin{tabular}{cccc}
\hline No. & L/P & $\begin{array}{c}\text { Skor } \\
\text { Tes }\end{array}$ & $\begin{array}{c}\text { Ketuntasan } \\
\text { Individu }\end{array}$ \\
\hline 1 & L & 85 & Tuntas \\
\hline 2 & P & 100 & Tuntas \\
\hline 3 & P & 80 & Tuntas \\
\hline 4 & P & 75 & Tuntas \\
\hline 5 & P & 75 & Tuntas \\
\hline 6 & L & 65 & Tidak Tuntas \\
\hline 7 & L & 80 & Tuntas \\
\hline 8 & L & 75 & Tuntas \\
\hline 9 & P & 75 & Tuntas \\
\hline 10 & P & 56 & Tidak Tuntas \\
\hline 11 & P & 80 & Tuntas \\
\hline 12 & L & 75 & Tuntas \\
\hline 13 & L & 80 & Tuntas \\
\hline 14 & L & 85 & Tuntas \\
\hline 15 & P & 60 & Tidak Tuntas \\
\hline
\end{tabular}

Dari hasil tes akhir yang diperoleh menunjukan bahwa ada 3 orang siswa yang belum mencapai ketuntasan individu, hal ini sesuai dengan acuan standar ketuntasan belajar, siswa dikatakan berhasil tuntas secara individu jika sudah mencapai nilai 75 atau lebih. Sedangkan acuan standar secara klasikal kelas dikatakan tuntas jika telah mencapai minimal $75 \%$ atau lebih dari jumlah siswa yang telah mencapai ketuntasan belajar. Dari nilai tes akhir ketuntasan belajar siswa secara individu terdapat 12 orang siswa yang tuntas belajar. Persentase perhitungan ketuntasan belajar secara klasikal dapat dipersentasekan sebagai berikut:

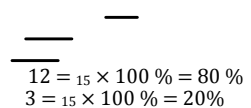

Dari hasil persentase ketuntasan belajar secara klasikal diperoleh sebesar $80 \%$, sedangkan persentase siswa yang belum mencapai ketuntasan belajar sebesar , maka secara klasikal kelas tersebut dikatakan tuntas dalam pembelajaran matematika realistik pada materi penjumlahan dan pengurangan bilangan bulat.

\section{Pembahasan}

Penelitian ini merupakan penelitian kualitatif mempunyai tujuan untuk mendeskripsikan tentang aktivitas siswa kelas IV SDN Jenangan, Kwadungan, Ngawi selama proses pembelajaran realistik berlangsung pada materi penjumlahan dan pengurangan bilangan 
bulat dan ketuntasan belajar siswa kelas IV SDN Jenangan, Kwadungan, Ngawi setelah diajar dengan pembelajaran matematika realistik pada materi penjumahan dan pengurangan bilangan bulat. Dalam penelitian ini kriteria ketuntasan belajar siswa secara individu apabila siswa telah mencapai skor $\square 75$ dari skor maksimum 100, sedangkan kriteria ketuntasan secara klasikal apabila terdapat minimal $75 \%$ jumlah siswa dikelas yang telah mencapai skor

75.

Saat kegiatan pembelajaran, aktivitas siswa yang relevan dengan KBM sebesar 98,83 \%, sedangkan aktivitas siswa yang tidak relevan dengan KBM sebesar 10,15\%. Hal ini menunjukkan bahwa aktivitas siswa yang relevan dengan KBM lebih baik dari pada aktivitas siswa yang tidak relevan dengan KBM, dengan demikian aktivitas siswa dengan kategori sangan baik.

Pada tes akhir ada 3 orang siswa yang tidak tuntas belajar secara individu karena kurang telitinya siswa dalam mengurangkan dan menjumlahkan bilangan serta kurang teliti dalam membaca soal. Ada 12 orang siswa yang tuntas belajar. Adapun ketuntasan klasikal mencapai 80 $\%$, maka secara klasikal kelas tersebut dikatakan tuntas dalam pembelajaran matematika realistik pada materi penjumlahan dan pengurangan bilangan bulat.

\section{E. Kesimpulan dan Saran}

\section{Kesimpulan}

Berdasarkan hasil penelitian dalam pembelajaran matematika realistik pada materi penjumlahan dan pengurangan bilangan bulat pada siswa kelas IV SDN Jenangan, Kwadungan, Ngawi maka dapat disimpulkan bahwa:

1) aktivitas siswa yang relevan dengan KBM (kegiatan belajar mengajar) sebesar 98,83\% tergolong dalam kategori sangat baik. Sedangkan aktivitas siswa yang tidak relevan dengan KBM sebesar 10,15\%,

2) ketuntasan siswa dalam pembelajaran matematika realistik pada materi operasi hitung penjumlahan dan pengurangan bilangan bulat bagi siswa kelas IV SDN Jenangan, Kwadungan, Ngawi diperoleh ketuntasan belajar siswa secara individu sebannyak 12 orang siswa dari jumlah siswa seluruhnya sebanyak 15 orang siswa, yang tidak tuntas secara individu sebanyak 3 orang siswa. Sedangkan ketuntasan klasikal diperoleh $80 \%$ dari siswa yang tuntas belajar.

\section{Saran}

Beberapa saran yang dapat disampaikan berdasarkan hasil penelitian tentang pembelajaran matematika realistik pada materi penjumlahan dan pengurangan bilangan bulat pada siswa kelas IV SDN Jenangan, Kwadungan, Ngawi adalah sebagai berikut.

1) Guru hendaknya selalu memotivasi siswa selama proses pembelajaran untuk aktif dalam diskusi kelompok maupun presentasi hasil diskusi. 
2) Bagi peneliti yang berminat, diharapkan untuk menerapkan pembelajaran matematika realistik pada materi yang lain yang dapat direalistikkan seperti bangun ruang, ukuran, aritmatika sosial, dan sebagainya

\section{DAFTAR PUSTAKA}

Arindawati dan Huda. 2004. Beberapa Alternative Pembelajaran Disekolah Dasar "Menyongsong Kurikulum 2004”. Penerbit Bayumedia Publishing.

Inganah, Siti. 2003. Model Pembelajarn Segiempat dengan Pendekatan Realistik Pada Siswa Kelas 2 SLTP Negeri 3 Batu. Tesis tidak diterbitkan. Malang: PPS Universitas Negeri Malang.

Moleong, L. J. 2006. Metodologi Penelitian Kualitatif. Edisi Revisi. Cetakan ke-22. Bandung: PT Remaja Rosdakarya.

Russefendi, E.T. (2010). Perkembangan Pendidikan Matematika. Jakarta: Universitas Terbuka.

Suharta, I Gusti Putu. 2001. Matematika Realistik: Apa dan Bagaimana, (on line), (http://www.depdiknas.go.id/ jurnal/38/matematika\%20, diambil tanggal 7 Januari 2015).
Suryanto. 2007. Pendidikan Matematika Realistik Indonesia (PMRI): dalam PMRI (Pendidikan Matematika Realistik Indonesia). Volume V, No. 1, Januari 2007.

Wijaya, Aryadi. 2011. Pendidikan Matematika Realistik. Yogyakarta: Graha Ilmu 


\title{
PENGARUH PEMBELAJARAN KOOPERATIF MELALUI MEDIA PERMAINAN ULAR TANGGA TERHADAP HASIL BELAJAR SISWA MATA PELAJARAN IPS DI SEKOLAH DASAR
}

\author{
Maya Kartika Sari \\ Prodi PGSD FIP IKIP PGRI MADIUN
}

\begin{abstract}
Learning social studies in elementary dominated by the monotonous teaching methods, conventional and less effective, the teacher dominated learning, teaching by lecturing and recorded material, and using instructional media. This needs to be an improvement of learning. Researchers trying to implement cooperative learning methods through the media game of snakes and ladders as an attempt to create learning interesting, active, and can motivate student learning. This study aims to determine the effect of cooperative learning through the media cooperative game of snakes and ladders on learning outcomes of fourth grade students in academic year 2014/2015 Tembi Bantul. The study population was all students in fourth grade Tembi as experimental class and fourth grade students Bangeran as the control class. The samples were overall Tembi fourth grade students were 22 students and fourth grade students Bangeran as many as 11 students. This study design used quantitative research methods. Collecting data in this study used the test method. The test method used is the pre-test and post-test were given to the experimental group and the control group. Analysis of the data used is a statistical method t test $(t$-test). Results of the data analysis $t$ test $(t$-test $)$ obtained value $=$

12.7754. At the significance level $(\alpha)=0.05$ earned value $=2.0441$. Then thitung $\geq$ tabe is 12,7754

$\geq 2,0441$, then Ho is rejected and Ha accepted. The conclusion of this study was the influence of cooperative learning through the medium of snakes and ladders game on learning outcomes of students Subjects IPS in Tembi Bantul elementary school year 2014/2015.
\end{abstract}

Keywords : Cooperative Model, Media Snakes and Ladders, Learning Outcomes

\begin{abstract}
ABSTRAK
Pembelajaran IPS di SD didominasi oleh metode pembelajaran yang monoton, konvensional dan kurang efektif, yakni guru mendominasi pembelajaran, mengajar dengan berceramah dan mencatat materi, dan tidak menggunakan media pembelajaran. Hal ini perlu adanya perbaikan pembelajaran. Peneliti mencoba menerapkan metode pembelajaran kooperatif melalui media permainan ular tangga sebagai upaya untuk menciptakan pembelajaran yang menarik, aktif, dan dapat memotivasi belajar siswa. Penelitian ini bertujuan untuk mengetahui pengaruh metode pembelajaran kooperatif melalui media permainan ular tangga terhadap hasil belajar siswa kelas IV SD Tembi Bantul Tahun Pelajaran 2014/2015. Populasi penelitian ini adalah seluruh siswa kelas IV SD Tembi sebagai kelas experimen dan siswa kelas IV SD Bangeran sebagai kelas kontrol. Sampel penelitian adalah keseluruhan siswa kelas IV SD Tembi sebanyak 22 siswa dan siswa kelas IV SD Bangeran sebanyak 11 siswa. Penelitian ini menggunakan metode penelitian kuantitatif. Pengumpulan data menggunakan metode tes berupa pre-test dan post-test yang diberikan kepada kelompok eksperimen dan kelompok kontrol. Analisis data yang digunakan adalah metode statistik t test (uji-t). Hasil analisis data $\mathrm{t}$ test (uji-t) diperoleh nilai $=12,7754$. Pada taraf signifikansi $(\alpha)=$ 0,05 diperoleh nilai $=2,0441$. Maka thitung $\geq \mathrm{t}$ tabel yaitu $12,7754 \geq 2,0441$, maka Ho ditolak. Kesimpulan dari hasil penelitian ini adalah ada pengaruh metode pembelajaran kooperatif melalui media permainan ular tangga terhadap hasil belajar siswa Mata Pelajaran IPS di SD Tembi Bantul tahun pelajaran 2014/2015.
\end{abstract}

Kata Kunci: Model Kooperatif, Media Ular Tangga, Hasil Belajar. 


\section{A. Pendahuluan}

Pembelajaran IPS di Sekolah Dasar memiliki kecendungan kearah kepasifan dan kekurangkondusifan, hal ini dikarenakan guru dalam mengajar masih bersifat konvensional. Pengajaran yang dilakukan hanya menggunakan metode ceramah dikolaborasi dengan tanyajawab sederhana mengenai materi yang dibahas, dan kurang memperhatikan kondisi, keaktivan, dan motivasi belajar siswa. Hal ini berdampak pada kekurangminatnya siswa dalam mengikuti pembelajaran IPS serta kejenuhan siswa dalam belajar.

Permasalahan tersebut juga terjadi di SD Tembi Kabupaten Bantul, dimana guru menjelaskan materi pelajaran dengan metode yang monoton dan kurang bervariasi, tidak adanya media pembelajaran yang memudahkan siswa dalam memahami materi, kepasifan siswa dalam pembelajaran, dan kurangnya motivasi siswa dalam belajar yang terlihat dari banyaknya siswa yang tidak berkonsentrasi dalam belajar dan bermain sendiri. Dampaknya hasil belajar siswa menjadi tidak maksimal. Hal ini perlu adanya perbaikan pembelajaran agar hasil belajar siswa menjadi meningkat.

Perbaikan pembelajaran yang dapat dilakukan oleh guru yakni dengan mengubah gaya mengajar, penggunaan metode pembelajaran yang tepat dan menyenangkan, dan pemanfaatan media pembelajaran yang menarik. Metode pembelajaran merupakan cara penyampaian guru dalam pembelajaran dalam rangka mencapai tujuan. Metode pemebalajran yang tepat dan menyenangkan dapat meningkatkan keaktivan, motivasi dan hasil belajar siswa. Sedangkan Media pembelajaran merupakan alat bantu yang dipergunakan guru untuk menyampaikan materi pelajaran kepada siswa. Media pembelajaran dapat berupa media grafis, media audio, media proyeksi diam, dan media permainan. Guru dapat menciptakan dan mengembangkan suatu media pembelajaran berbasis permainan bagi siswa. Penggunaan metode bembelajaran yang interaktif dan menyenangkan juga media pembelajaran yang manarik akan berpengaruh terhadap kegiatan siswa selama proses belajar mengajar

Berdasarkan uraian tersebut diatas, maka peneliti bermaksud untuk memberikan treatmen pembelajaran yakni dengan menggunakan metode belajar kooperatif melalui media permainan ular tangga untuk meningkatkan hasil belajar siswa.

\section{B. Kajian Pustaka dan Hipotesis Penelitian}

1. Kajian Teori

a. Metode Pembelajaran Kooperatif Menurut Slavin (dalam Isjoni,

2011: 15) "pembelajaran kooperatif adalah suatu model pembelajaran dimana siswa belajar dan bekerja dalam kelompok-kelompok kecil secara 
kolaboratif yang anggotanya 4-6 orang dengan struktur kelompok heterogen".

Menurut Etin Solihatin dan Raharjo (2007: 4) pada dasarnya cooperative learning mengandung pengertian sebagai suatu sikap bersama dalam struktur kerja sama yang teratur dalam kelompok, yang terdiri dari dua orang atau lebih dimana keberhasilan kerja sangat dipengaruhi oleh keterlibatan dari setiap anggota kelompok itu sendiri.

Pembelajaran kooperatif memiliki beberapa prinsip dalam pelaksanaannya, menurut Stahl, 1994 (dalam Etin Solihatin dan Raharjo, 2007: 6-9) menyebutkan prinsip-prinsip dasar dalam Cooperative Learning, adalah :

1) Perumusan tujuan belajar siswa harus jelas,

2) penerimaan menyeluruh oleh siswa tentang tujuan belajar,

3) ketergantungan yang sangat positif,

4) interaksi yang bersifat terbuka,

5) tanggung jawab individu,

6) kelompok bersifat heterogen,

7) interaksi sikap dan perilaku sosial yang positif,

8) tindak lanjut (follow up),

9) kepuasan dalam belajar.

Dari penjelasan diatas dapat disimpulkan bahwa pembelajaran kooperatif adalah suatu aktivitas pembelajaran yang menggunakan pola belajar siswa berkelompok untuk menjalinkerjasama dan saling ketergantungan positif sehingga tercapai proses dan hasil belajar yang produktif. Siswa yang belajar dengan model pembelajaran kooperatif akan memiliki motivasi yang tinggi karena didorong oleh rekan sebaya.

b. Media Pembelajaran Ular Tangga

Media pembelajaran adalah segala sesuatu yang dapat digunakan untuk menyalurkan pesan dari pengirim ke penerima sehingga dapat merangsang pikiran, perasaan, perhatian dan minat siswa sedemikian rupa sehingga terjadi proses belajar (Suwarna, 2005:126)

Media pembelajaran menurut Romiszowski (dalam Harjanto, 2005: 247) dinyatakan bahwa media pembelajaran

... as the carriers of massaes, from some transmitting source (with may be a human being or an intimate object), to the receiver of the massage (which is our case is the learner).

Menurut pendapat Romiszowski menyatakan bahwa media pembelajaran yakni penyampaian pesan (carriers of information) berinteraksi dengan siswa melalui pengindraannya siswa dapat dipanggil untuk menggunakan sesuatu alat indranya untuk menerima informasi, atau dapat juga menggunakan kombinasi alat indra sekaligus, sehingga kegiatan bekomunikasi lebih saksama.

Berdasarkan pendapat tersebut maka Media pembelajaran merupakan alat bantu yang dipergunakan guru untuk menyampaikan materi pelajaran kepada siswa dimana media pembelajaran akan memudahkan siswa dalam menerima pelajaran, siswa dapat terlibat langsung 
dalam proses pembelajaran dan menarik siswa untuk aktif dalam proses belajar.

Media pembelajaran dapat berupa media grafis, media audio, media proyeksi diam, dan media permainan. Guru dapat menciptakan dan mengembangkan suatu media pembelajaran berbasis permainan bagi siswa. Penggunaan media pembelajaran akan berpengaruh terhadap kegiatan siswa selama proses belajar mengajar. Pemilihan media pembelajaran harus disesuaikan dengan materi yang diajarkan dan kondisi siswa, sehingga diharapkan siswa dapat terlibat secara aktif dalam kegiatan pembelajaran. Seorang guru harus mampu memilih media pembelajaran yang tepat agar siswa dapat termotivasi untuk berperan aktif dalam pembelajaran.

Media pembelajaran yang dapat diciptakan oleh guru adalah permainan ular tangga. Permainan ular tangga dapat dijadikan sebagai media pembelajaran yang menyenangkan bagi siswa. Siswa akan cenderung tertarik mengikuti proses pembelajaran. Dalam hal ini, guru berperan sebagai fasilitator bagi siswa. Siswa yang aktif dalam permainan ular tangga dapat menemukan sendiri konsep materi yang sedang dipelajari. Sebab metode dalam permainan ular tangga dipadukan dengan diskusi kelompok. Dalam diskusi kelompok ini siswa diberikan suatu permasalahan yang berkaitan dengan materi dalam kehidupan sehari-hari.

c. Pembelajaran IPS di Sekolah Dasar Ilmu Pengetahuan Sosial IPS

menurut Moeljono Cokrodikardjo (dalam Maya Kartika, 2012:2) didefinisikan sebagai perwujudan suatu pendekatan interdisipliner dari ilmu sosial yang merupakan integritas dari berbagai ilmu sosial yakni sosiologi, antropologi budaya, psikologi, sejarah, geografi, ekonomi, ilmu politik dan ekologi manusia yang diformulasikan untuk tujuan instruksional dengan materi dan tujuan yang disederhanakan agar mudah dipahami.

Tujuan pembelajaran IPS menurut Jackson (2004) mengatakan bahwa : the purpose of sosial studies is to prepare youth for citizenship, there's also general agreement that the elements of a sound citizenship education are knowledge, skills, values, and participation. Sejalan dengan pendapat tersebut Cheft (1991) mengemukakan bahwa pembelajaran IPS berusaha membantu siswa dalam memecahkan permasalahan-permasalahan yang dihadapi, sehingga akan menjadikan semakin mengerti dan memahami lingkungan sosial masyarakatnya

Pendidikan IPS SD disajikan dalam bentuk synthetic science, karena basis dari disiplin ilmu ini terletak pada fenomena yang telah diobservasi di dunia nyata. Konsep, generalisasi, dan temuan-temuan penelitian dari synthetic science, ditentukan setelah fakta terjadi atau observasi dan tidak sebelumnya. 
Pola pembelajaran IPS di SD hendaknya lebih menekankan pada unsur pendidikan dan pembekalan pemahaman, nilai-moral, dan keterampilan-keterampilan sosial pada siswa. Rancangan pembelajaran guru, hendaknya diarahkan dan di fokuskan sesuai dengan kondisi dan perkembangan potensi siswa agar pembelajaran yang dilakukannya benar-benar berguna dan bermanfaat bagi siswa. Pembelajaran Pendidikan IPS semestinya diarahkan pada upaya pengembangan iklim yang kondusif bagi siswa untuk belajar sekaligus melatih pengetahuan, sikap, nilai dan keterampilannya selama pembelajaran, disamping memungkinkan siswa untuk terlibat secara langsung dalam proses belajar mengajar.

d. Kajian Hasil Belajar

Hasil belajar adalah perubahan-perubahan yang terjadi pada diri siswa,baik yang menyangkut aspek kognitif, afektif, dan psikomotorik sebagai hasil dari kegiatan pembelajaran. Bloom (dalam Jihad dan Aris, 2012: 14) berpendapat bahwa hasil belajar dapat dikelompokkan ke dalam dua macam yaitu:

1) Pengetahuan terdiri dari empat kategori, yaitu;
a) Pengetahuan tentang fakta
b) Pengetahuan tentang posedural
c) Pengetahuan tentang konsep
d) Pengetahuan tentang prinsip

2) Keterampilan juga terdiri dari empat kategori, yaitu:

a) Keterampilan untuk berfikir atau keterampilan kognitif

b) Keterampilan untuk bertindak atau keterampilan motorik

c) Keterampilan bereaksi atau bersikap

d) Keterampilan berinteraksi

Untuk memperoleh hasil belajar, dilakukan evaluasi atau penilaian yang merupakan tindak lanjut atau cara untuk mengukur tingkat penguasaan siswa. Kemajuan prestasi belajar siswa tidak saja diukur dari tingkat penguasaan ilmu pengetahuan tetapi juga sikap dan keterampilan. Dengan demikian penilaian hasil belajar siswa mencakup segala hal. Hasil belajar sebagaimana telah dijelaskan di atas meliputi pemahaman konsep konsep (aspek kognitif), keterampilan proses (aspek psikomotorik), dan sikap siswa (aspek afektif)

2. Kerangka Berpikir

Pembelajaran IPS disekolah lebih banyak didominasi oleh guru dan menggunakan metode pembelajaran yang konvensional. Pembelajaran IPS yang memuat hafalan-hafalan materi yang menuntut guru untuk mengejar target materi yang harus diajarkan sehingga guru terkadang menyampaikan materi hanya dengan berceramah dan mencatat saja. Hal ini menimbulkan kebosanan dan kejenuhan siswa dalam belajar, sehingga hasil belajar siswa tidak maksimal.

Berdasarkan permasalahan diatas perlu adanya perbaikan pembelajaran agar hasil belajar mata pelajaran IPS menjadi meningkat, yakni dengan penerapan variasi metode dan media 
pembelajaran. Salah satu metode pembelajaran yang dapat mengaktifkan siswa yakni metode kooperatif. Dengan metode kooperatif siswa dapat terlibat langsung dalam pembelajaran, siswa dapat bekerjasama dan saling percaya dengan teman, dan keaktifan siswa menjadi lebih baik. Metode kooperatif pada penelitian ini menggunakan media permainan ular tangga, dimana dibutuhkan kolaborasi yang baik antar siswa dalam rangka menyelesaikan permainan. Permainan ular tangga merupakan media pembelajaran yang interaktif dan menarik, dapat memecahkan kejenuhan belajar dan siswa dapat memahami materi lebih baik. Harapannya melalui metode kooperatif berbantu media permainan ular tangga dapat meningkatkan hasil belajar siswa kelas IV SD Ngoto Bantul.

Berikut ini kerangka berfikir pengaruh Metode Pembelajaran Kooperatif Melalui Media Permainan Ular Tangga Terhadap Hasil Belajar Siswa kelas IV pada mata pelajaran IPS.



Gambar 1. Kerangka Berfikir
3. Hipotesa penelitian

Hipotesa berupa dugaan sementara terhadap hasil penelitian. Berdasarkan permasalahan diatas maka dirumuskan Hipotesa dalam penelitian ini yakni ;

Ho = Tidak ada pengaruh Metode Pembelajaran Kooperatif Melalui Media Permainan Ular Tangga Terhadap Hasil Belajar Siswa Mata Pelajaran IPS di SD Tembi Bantul Tahun Pelajaran 2014/2015

$\mathrm{Ha}=$ Ada pengaruh Metode Pembelajaran Kooperatif Melalui Media Permainan Ular Tangga Terhadap Hasil Belajar Siswa Mata Pelajaran IPS di SD Tembi Bantul Tahun Pelajaran 2014/2015

Hipotesa ini akan terbukti melalui penelitian yang akan dilakukan melalui uji hipotesa berdasarkan hasil penelitian.

\section{Metode Penelitian}

\section{Setting Penelitian}

Penelitian ini dilaksanakan di SD Tembi dan SD Bangeran Kabupaten Bantul. Waktu penelitian 2 bulan yakni pada bulan Maret 2015 sampai April 2015 dengan tahapan pengajuan proposal, pengumpulan data, pengolahan data dan pembuatan laporan akhir penelitian.

2. Rancangan Penelitian

a. Metode Penelitian

Metode penelitian ini menggunakan metode eksperimen untuk mencari pengaruh perlakuan 
tertentu terhadap yang lain dalam kondisi terkendalikan. penelitian tersebut dilakukan dengan baik, maka dapat menjawab hipotesis yang utamanya berkaitan dengan hubungan sebab akibat serta berapa besar hubungan sebab akibat tersebut dengan cara memberikan perlakuan-perlakuan tertentu pada kelompok eksperimen dan menyediakan kontrol untuk perbandingan

\section{b. Desain Penelitian}

Desain penelitian
menggunakan Pre-Test-Post-
Test Control Group Design.
Dimana terdapat dua kelompok yaitu kelompok eksperimen dan kelompok kontrol atau pembanding. Kelompok pertama diberi perlakuan (X) yang disebut kelompok eksperimen dan kelompok yang lain tidak diberi perlakuan yang disebut kelompok pembanding atau kelompok kontrol (Y). Kedua kelompok ini diberi pengukuran yang sama yaitu Pretest (tes sebelum pembelajaran) dan Posttest (tes setelah pembelajaran).

c. Variabel Penelitian

Dalam penelitian ini terdapat dua variabel yaitu variabel bebas dan variabel terikat. Variabel bebas dalam penelitian ini adalah metode pembelajaran kooperatif melalui media permainan ular tangga.
Sedangkan Variabel terikat dalam penelitian ini adalah hasil belajar siswa kelas IV pada mata pelajaran IPS

3. Data dan cara pengumpulan data a. Sumber dan jenis data

Sumber data dari penelitian ini adalah populasi siswa kelas IV di SD Tembi (kelas Experimen) sebanyak 22 orang, dan siswa kelas IV SD Bageran (kelas kontrol) Sebanyak 11 orang. Sampel dalam penelitian ini yakni siswa kelas IV SD Tembi (kelas Experimen) sebanyak 22 orang dan siswa kelas IV SD Bageran (kelas kontrol) sebanyak 11 orang. Teknik pengambilan sampel yakni menggunakan teknik sample jenuh yakni keseluruhan dari populasi diambil untuk dijadikan sampel penelitian.

Jenis data pada penelitian ini adalah data kuantitatif, yakni peneliti melakukan pengukuran menggunakan angka kemudian mendeskripsikan hasil penelitian yang telah didapatkan.

b. Teknik pengambilan data

Metode pengumpulan data yang digunakan dalam penelitian ini adalah teknik tes. Tes yang digunakan adalah pretest dan posttest yang diberlakukan sama antara kelas kontrol dan kelas eksperimen, namun dengan metode yang berbeda.

Tes yang digunakan dalam penelitian ini telah dilakukan uji validitas dan reliabelitas terhadap soal yang akan diberikan kepada siswa. Berdasarkan hasil uji validitas yang dilakukan terhadap instrumen tes yakni terdapat 22 soal yang valid sehingga 
peneliti menggunakan 20 soal untuk diberikan kepada siswa, sedangkan hasil reliabelitas instrumen tes diperoleh nilai $>$ yaitu $0,937>0,576$, maka tes dikatakan reliabel. Ini berarti instrumen tes hasil belajar tersebut reliabel, sehingga dapat digunakan untuk mengetahui tingkat hasil belajar siswa.

c. Teknik Analisa Data

Data dalam penelitan ini melalui uji normalitas dan uji homogenitas. Uji normalitas menggunakan metode lilliefors dengan taraf signifikansi $(\alpha)$ sebesar 0,05, dan uji homogenitas menggunakan uji F. Setelah itu dilakukan uji hipotesis apabila seluruh komponen penelitian telah diuji keabsahannya. Tujuan untuk mengetahui pengaruh metode pembelajaran kooperatif melalui media permainan ular tangga terhadap hasil belajar siswa kelas IV pada mata pelajaran IPS di SD Tembi Bantul. Data ini bersifat data interval. Untuk mengukur data interval dan terdapat kelompok eksperimen dan kelompok kontrol, maka analisis data menggunakan statistik dengan rumus " $t$ " test. Rumus " $\mathrm{t}$ " test yang digunakan adalah:

$$
t=\frac{\bar{x}_{1}-\bar{x}_{2}}{s_{g a b} \sqrt{\frac{1}{n_{1}}+\frac{1}{n_{2}}}}
$$

Langkah analisa data yang dilakukan peneliti yakni menulis $\mathrm{H}_{\mathrm{a}}$ dan $H_{0}$ dalam bentuk kalimat dan angka statistik, menghitung nilai t tes, menentukan taraf signifikan $\alpha=95 \%$ atau 99\%, mencari tabel dengan pengujian dua pihak dimana $\mathrm{dk}=\mathrm{n}_{1}+$ n2-2, menentukan kriteria pengujian yakni Ha diterima jika thitung > tabel, membandingkan thitung dengan tabel, dan membuat kesimpulan. Dengan menggunakan uji t tersebut akan dapat diketahui hasil penelitian dikelas kontrol dan kelas eksperimen, sehingga peneliti dapat menyimpulkan hasil penelitian yang relevan.

\section{Hasil Penelitian dan Pembahasan \\ 1. Deskripsi Data}

Data yang disajikan pada penelitian ini adalah data tes yakni pretest dan posttest siswa kelas IV SD Tembi setelah mendapat perlakuan dengan metode pembelajaran kooperatif melalui media permainan ular tangga dan SD Bageran setelah mendapat perlakuan dengan metode pembelajaran konvensional. Berikut akan dijelaskan data pretest dan posttest tersebut yaitu:

a. Data Pre-tes Hasil Belajar IPS

(sebelum mendapat perlakuan) di kelas kontrol dan experimen

Data nilai Pre-test hasil belajar IPS adalah data keadaan awal sebelum mendapat perlakuan yang diperoleh dari nilai pre-test hasil belajar pada kelas IV SD Tembi (kelas eksperimen) dan kelas IV SD Bageran (kelas kontrol). Berdasarkan data nilai pre-test hasil belajar IPS siswa kelas eksperimen dan 
kelas kontrol menunjukkan bahwa kelas IV SD Tembi (kelas eksperimen) dari 22 siswa diperoleh nilai tertinggi sebesar 90 , nilai terendah 55 dengan rata-rata sebesar 73,86 ; median (nilai tengah) sebesar 77,5; modus (nilai yang sering muncul) sebesar 80 dan standar deviasi sebesar 9,75.

Pada siswa kelas IV SD Bageran (kelas kontrol) dari 11 siswa diperoleh nilai tertinggi sebesar 95, nilai terendah sebesar 60 dengan rata-rata sebesar 76,82 ; median (nilai tengah) sebesar 75 ; modus (nilai yang sering muncul) sebesar 85 dan standar deviasi sebesar 11,24.

Gambaran lebih jelas mengenai data nilai pre-test hasil belajar IPS siswa kelas IV SD Tembi (kelas eksperimen) dan kelas IV SD Bageran (kelas kontrol) dapat dilihat pada tabel nilai pre-test hasil belajar IPS yakni:

Tabel. 1. Hasil nilai Pre-tes

\begin{tabular}{lcc}
\hline \multirow{2}{*}{ Hasil } & \multicolumn{2}{c}{ Pre test hasil belajar } \\
\cline { 2 - 3 } & $\begin{array}{c}\text { Kelas } \\
\text { experimen }\end{array}$ & $\begin{array}{c}\text { Kelas } \\
\text { kontrol }\end{array}$ \\
\hline N (jumlah & 22 & 11 \\
siswa) & 90 & 95 \\
\hline$X_{\text {maks }}$ (Skor & \\
maksimal) & & 60 \\
\hline $\begin{array}{l}\text { Xmin (Skor } \\
\text { minimal) }\end{array}$ & 55 & 76,82 \\
\hline (Rata-rata) & 73,86 & 11,24 \\
\hline $\begin{array}{l}\text { S (simpangan } \\
\text { baku) }\end{array}$ & 9,75 & \\
\hline
\end{tabular}

b. Data post tes Hasil Belajar IPS (setelah mendapat perlakuan) di kelas kontrol dan experimen

Pemberian post-test hasil belajar IPS dilakukan setelah siswa kelas IV SD Tembi mendapatkan perlakuan berupa metode pembelajaran kooperatif melalui media permainan ular tangga dan kelas IV SD Bageran dengan model pembelajaran yang digunakan oleh guru sehari-hari yaitu konvensional. Berdasarkan nilai post-test menunjukkan bahwa kelas IV SD Tembi (kelas eksperimen) dari 22 siswa diperoleh nilai tertinggi sebesar 100 , nilai terendah 70 dengan rata-rata sebesar 81,82 , median (nilai tengah) sebesar 82,5, modus (nilai yang sering muncul) sebesar 85 dan standar deviasi sebesar 9,20.

Pada siswa kelas IV di SD Bageran (kelas kontrol) dari 11 siswa diperoleh nilai tertinggi sebesar 85 , nilai terendah sebesar 50 dengan rata-rata sebesar 66,82 median (nilai tengah) sebesar 65, modus (nilai yang sering muncul) sebesar 80 dan standar deviasi sebesar 12,70 .

Gambaran lebih jelas mengenai data nilai post-test hasil belajar IPS siswa kelas IV SD Tembi (kelas eksperimen) dan kelas IV SD Bageran (kelas kontrol) dapat dilihat pada tabel nilai post-test hasil belajar IPS berikut ini:

Tabel. 2. Hasil nilai Post-tes

\begin{tabular}{lcc}
\hline \multirow{2}{*}{ Hasil } & \multicolumn{2}{c}{ Post-test hasil belajar } \\
\cline { 2 - 3 } & $\begin{array}{c}\text { Kelas } \\
\text { experimen }\end{array}$ & $\begin{array}{c}\text { Kelas } \\
\text { kontrol }\end{array}$ \\
\hline N (jumlah siswa) & 22 & 11 \\
\hline $\begin{array}{l}\text { Xmaks (Skor } \\
\text { maksimal) }\end{array}$ & 100 & 85 \\
\hline$X_{\text {min } \text { (Skor minimal) }}$ & 70 & 50 \\
\hline (Rata - rata) & 81,82 & 66,82 \\
\hline S (simpangan baku) & 9,20 & 12,70 \\
\hline
\end{tabular}


c. Perhitungan Pretest dan Posttest

Kelompok Eksperimen dan Kontrol

Berdasarkan pengolahan data pretest dan posttest siswa kelas IV pada mata pelajaran IPS dengan menggunakan metode pembelajaran kooperatif melalui media permainan ular tangga (kelas eksperimen) dan menggunakan metode pembelajaran konvensional (kelas kontrol). Maka diperoleh hasil pengolahan data sebagai berikut:

Tabel 3. Hasil Pengolahan Nilai Pretest dan Posttest

\begin{tabular}{|c|c|c|c|c|}
\hline \multirow{2}{*}{ Hasil } & \multicolumn{2}{|c|}{$\begin{array}{c}\text { Kelas } \\
\text { Eksperimen }\end{array}$} & \multicolumn{2}{|c|}{$\begin{array}{c}\text { Kelas } \\
\text { Kontrol } \\
\end{array}$} \\
\hline & $\begin{array}{l}\text { Pre- } \\
\text { Test }\end{array}$ & $\begin{array}{l}\text { Post- } \\
\text { Test }\end{array}$ & $\begin{array}{l}\text { Pre- } \\
\text { Test }\end{array}$ & $\begin{array}{c}\text { Post- } \\
\text { Test }\end{array}$ \\
\hline $\begin{array}{l}\mathrm{N} \text { (jumlah } \\
\text { siswa) }\end{array}$ & 22 & 22 & 11 & 11 \\
\hline $\begin{array}{l}\text { maks }(\text { Skor } \\
\text { maksimal) }\end{array}$ & 90 & 100 & 95 & 85 \\
\hline $\begin{array}{l}X_{\min }(\text { Skor } \\
\text { minimal) } \\
\end{array}$ & 55 & 70 & 60 & 50 \\
\hline (Rata - rata) & 73,86 & 81,82 & $\begin{array}{c}76,8 \\
2 \\
\end{array}$ & 66,82 \\
\hline $\begin{array}{l}\text { S (simpangan } \\
\text { baku) }\end{array}$ & 9,75 & 9,20 & $\begin{array}{c}11,2 \\
4\end{array}$ & 12,70 \\
\hline
\end{tabular}

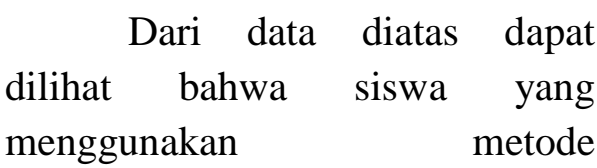
pembelajaran kooperatif melalui media permainan ular tangga mempunyai nilai rata-rata pretest 73,86 dengan nilai maksimal 90 serta minimal 55 dan nilai rata-rata posttest 81,82 dengan nilai maksimal 100 serta nilai minimal 70.

Sedangkan siswa yang diajar dengan menggunakan model pembelajaran konvensional mempunyai nilai rata-rata pretest 76,82 dengan nilai maksimal 95 serta minimal 60 dan nilai rata-rata posttest 66,82 dengan nilai maksimal 85 serta nilai minimal 50.

Berdasarkan pernyataan diatas, dapat disimpulkan bahwa rata-rata nilai tes IPS siswa kelas eksperimen lebih baik dibandingkan rata-rata nilai pada kelas kontrol. Hal ini berarti hasil tes belajar pada kelas eksperimen yang menggunakan metode pembelajaran kooperatif melalui media permainan ular tangga lebih baik dibandingkan hasil tes belajar pada kelas kontrol yang hanya menggunakan metode pembelajaran konvensional.

\section{Analisa Data}

Analisis data dilakukan untuk menguji kebenaran hipotesis yang diajukan dalam penelitian ini yaitu ada pengaruh penggunaan metode pembelajaran kooperatif melalui media permainan ular tangga pada mata pelajaran IPS terhadap hasil belajar siswa kelas IV di SD Tembi dan siswa kelas IV di SD Bangeran tahun pelajaran 2014/2015.

Untuk mengetahui kebenaran hipotesis ini maka penulis membandingkan hasil belajar belajar IPS siswa kelas eksprimen yang menggunakan metode pembelajaran kooperatif melalui media permainan ular tangga dan kelas kontrol yang menggunakan metode pembelajaran konvensional. Sebelum membuktikan hipotesis, langkah-langkah yang terlebih dahulu dilakukan adalah melakukan uji normalitas dan uji homogenitas. 
a) Hasil Analisis Uji Normalitas

Uji normalitas digunakan

untuk mengetahui apakah data sampel tersebut berasal dari populasi yang berdistribusi normal atau tidak. Pada penelitian ini, uji normalitas dihitung dengan menggunakan metode lilliefors dengan taraf signifikansi $(\alpha)$ sebesar 0,05 (penghitungan selengkapnya dapat dilihat pada lampiran 10. Kriteria ujinya sebagai berikut:

- Ho diterima jika Lobs $\leq$ Ltabel

- Ho ditolak jika Lobs > Ltabel

Hasil uji normalitas Lilifors

untuk kelas IV di SD Tembi (kelas eksperimen) dengan tingkat $\alpha=$ 0,05 menunjukkan bahwa nilai koefisien $L=0,13651 \leq$ Ltabel =0,249, Ini berarti $H o$ diterima, sehingga dapat disimpulkan bahwa data sampel untuk kelas eksperimen berasal dari populasi yang berdistribusi normal.

Uji normalitas Lilifors untuk kelas IV di SD Bangeran (kelas kontrol) dengan tingkat $\alpha=$ 0,05 menunjukkan bahwa niliai koefisien $L=0,19327 \leq$ Ltabel=0,249. Ini berarti Ho diterima, sehingga dapat disimpulkan bahwa data sampel untuk kelas kontrol berasal dari populasi yang berdistribusi normal. b) Hasil Analisis Uji Homogenitas

Uji homogenitas digunakan untuk mengetahui apakah sampel data pengamatan kelompok eksperimen dan kontrol memiliki variansi yang homogen. Hasil analisis uji homogenitas pre-test dengan uji $\mathrm{F}$ pada tingkat signifikansi $\alpha=0,05$ menunjukkan bahwa $\mathrm{F}$ hitung $\leq \mathrm{F}$ tabel atau $1,33 \leq 3,31$. Sedangkan hasil analisis uji homogenitas post-test dengan uji $\mathrm{F}$ pada tingkat signifikansi $\alpha=0,05$ menunjukkan bahwa $\mathrm{F}$ hitung $\leq \mathrm{F}$ tabel atau $1,91 \leq 3,31$. Ini berarti Ho diterima, sehingga dapat disimpulkan bahwa data sampel kedua kelompok homogen.

c) Hasil Analisis Uji Hipotesis

Dalam penelitian ini uji hipotesis yang digunakan adalah uji t. Uji t tersebut digunakan untuk mengetahui apakah ada pengaruh metode pembelajaran kooperatif melalui media permainan ular tangga terhadap hasil belajar IPS siswa kelas IV di SD Tembi Bantul tahun ajaran 2014/2015. Uji hipotesis pada penelitian ini menggunakan uji $\mathrm{t}$ dengan varian homogen dan tingkat signifikasi 5\%, kriteria ujinya sebagai berikut:

$\mathrm{H}_{1}$ diterima jika thitung $>$ t tabel

$\mathrm{H}_{1}$ ditolak jika thitung $<\mathrm{t}_{\text {tabel }}$

Keterangan:

$\mathrm{H}_{\mathrm{o}}: \mu_{1}=\mu_{2}$ (Tidak ada pengaruh metode pembelajaran kooperatif melalui media permainan ular tangga terhadap hasil belajar IPS siswa kelas IV di SD Tembi Bantul tahun ajaran 2014/2015).

$\mathrm{H}_{1}: \mu_{1} \neq \mu_{2} \quad$ (Ada pengaruh metode pembelajaran kooperatif melalui media permainan ular tangga terhadap hasil belajar IPS siswa kelas IV di SD Tembi Bantul tahun ajaran 2014/2015).

Berdasarkan hasil analisis data, diperoleh thitung $=12,7754$ dan tabel $=$ 2,0441. Karena thitung > tabel, maka Ha diterima dan Ho ditolak. Kesimpulannya 
bahwa ada pengaruh metode pembelajaran kooperatif melalui media permainan ular tangga terhadap hasil belajar IPS siswa kelas IV di SD Tembi Bantul tahun ajaran 2014/2015

\section{Pembahasan}

Dalam

penelitian

eksperimen ini, pembelajaran terhadap kedua kelompok dilakukan dengan cara yang berbeda. Kelompok pertama sebagai kelas eksperimen menggunakan metode pembelajaran kooperatif melalui media permainan ular tangga, sedangkan kelompok kedua sebagai kelas kontrol menggunakan metode pembelajaran konvensional. Untuk mengetahui tingkat penguasaan siswa terhadap materi pelajaran yang dalam pembelajaran dilakukan dengan cara yang berbeda, peneliti mengukurnya melalui hasil tes belajar siswa. Tes yang dilakukan ini sebanyak dua kali yaitu yang disebut pretest (tes sebelum proses pembelajaran) dan posttest (tes setelah proses pembelajaran).

Pembelajaran di kelas eksperimen mendapat perlakuan dengan menggunakan metode pembelajaran kooperatif melalui media permainan ular tangga. Pada proses pembelajaran siswa merasa senang dan antusias dalam mengikuti pembelajaran, hal ini dikarenakan siswa terlibat langsung dalam pembelajaran, siswa menjadi aktif dan kejenuhan dalam pembelajaran dapat dihilangkan. Pada pemebalajran ini materi yang disampaikan guru telah tersaji dalam permainan ular tangga dan siswa dapat menguasai materi dengan baik karena penyajian materi diberikan dengan metode permainan. Berdasarkan hasil penelitian, pada saat pengujian pretest siswa dikelas experimen mendapatkan nilai tertinggi 90 , nilai terendah 55, dan rata-rata nilai pre-test sebesar 73,86. Sedangkan pada saat pengujian post-tes siswa dikelas experimen mendapatkan nilai tertinggi 100 , nilai terendah 70 , dan rata-rata nilai post-test sebesar 81,82 . Hal ini telah menunjukkan bahwa setelah mendapatkan perlakuan dengan menggunakan metode pembelajaran kooperatif melalui media permainan ular tangga terdapat peningkatan hasil belajar siswa kelas IV di SD Tembi.

Sedangkan pembelajaran yang dilakukan pada kelompok kontrol dengan menggunakan metode pembelajaran konvensional, penyampaian materi sepenuhnya berasal dari penjelasan guru dan siswa hanya mendengarkan penjelasan tersebut. Guru dalam pembelajaran banyak menggunakan ceramah, hal ini tidak menarik perhatian siswa dan kurang efektif dalam pembelajaran. Siswa kurang antusias dalam mempelajari materi tersebut, hanya terlihat siswa yang pandai saja yang terlihat aktif. Pada akhir pembelajaran juga diberi tes akhir seperti pada kelas eksperimen, akan tetapi hasil yang didapat oleh kelas kontrol tidak begitu memuaskan dan hanya siswa yang 
pandai saja yang mendapat nilai yang baik. Berdasarkan hasil penelitian, pada saat pengujian pretest siswa dikelas kontrol mendapatkan nilai tertinggi 95 , nilai terendah 60 , dan rata-rata nilai pretest sebesar 76,82. Sedangkan pada saat pengujian post-tes siswa dikelas kontrol mendapatkan nilai tertinggi 85 , nilai terendah 50 , dan rata-rata nilai post-test sebesar 66,82 . Hal ini menunjukkan pembelajaran dikelas kontrol dengan menggunakan metode konvensional kurang diminati oleh siswa.

Dari paparan diatas, pembelajaran yang menggunakan metode pembelajaran kooperatif melalui media permainan ular tangga lebih efektif dibandingkan dengan pembelajaran menggunakan metode konvensional. Terbukti dari hasil tes belajar siswa pada mata pelajaran IPS, siswa kelas eksperimen yang menggunakan metode pembelajaran kooperatif melalui media permainan ular tangga memiliki rata-rata nilai kelas yang lebih tinggi dibanding dengan nilai rata-rata siswa kelas kontrol yang menggunakan metode pembelajaran konvensional.

Berdasarkan hasil uji hipotesis yang telah dilakukan dapat diketahui bahwa thitung $=$

12,7754 dan $=2,0441$.

Sehingga dapat disimpulkan bahwa penggunaan metode pembelajaran kooperatif melalui media permainan ular tangga berpengaruh terhadap hasil belajar IPS dengan taraf signifikansi $5 \%$ atau 0,05 . Hal ini semakin diperkuat dengan hasil belajar yang diperoleh pada kelas kontrol dan kelas eksperimen, yaitu untuk kelas kontrol dengan jumlah siswa 11 anak memiliki nilai rata-rata 66,82 . Sedangkan pada kelas ekperimen dengan jumlah siswa 22 anak memiliki nilai ratarata 81,82. Berdasarkan data tersebut terbukti bahwa pembelajaran di kelas ekperimen yang menggunakan metode pembelajaran kooperatif melalui media permainan ular tangga memiliki rata-rata yang lebih baik bila dibandingkan dengan kelas kontrol yang menggunakan metode pembelajaran konvensional.

Kesimpulan dari penelitian ini yaitu ada pengaruh yang signifikan penggunaan metode pembelajaran kooperatif melalui media permainan ular tangga terhadap hasil belajar IPS siswa kelas IV SD Tembi Bantul Tahun Pelajaran 2014/2015.

\section{E. Penutup}

Dari analisis data dan pembahasan yang telah disampaikan dapat disimpulkan sebagai berikut:

1. Ada perbedaan hasil belajar siswa dengan menggunakan metode pembelajaran kooperatif melalui media permainan ular tangga dan hasil belajar siswa dengan menggunakan metode pembelajaran konvensional. Hal ini dapat dilihat dari rata-rata nilai kelas experimen lebih tinggi dibandingan dengan kelas kontrol yakni nilai ratarata kelas experimen 
sebesar 81,82 dan nilai rata-rata kelas kontrol sebesar 66,82.

2. Berdasarkan hasil analisis data, diperoleh thitung $=12,7754$ dan tabel $=2,0441$. Karena thitung > tabel, maka Ha diterima dan Ho ditolak. Kesimpulannya bahwa ada pengaruh metode pembelajaran kooperatif melalui media permainan ular tangga terhadap hasil belajar IPS siswa kelas IV di SD Tembi Bantul tahun ajaran 2014/2015

\section{Daftar Pustaka}

Agus Supijono. 2011. Cooperative Learning Teori dan Aplikasi PAIKEM. Yogyakarta: Pustaka Pelajar.

Asep Jihad dan Abdul Haris. (2008). Evaluasi Pembelajaran. Yogyakarta : Multipressindo

Arsyad, Azhar. 2002. Media Pembelajaran. Jakarta: Raja Grafindo Persada

Harjanto. 2005. Perencanaan Pengajaran. Jakarta: Rineka Cipta

Suwarna. 2005. Pengajaran Mikro. Yogyakarta: Tiara Wacana

Etin Solihatin dan Raharjo. 2007. Cooperative Analisis Model Pembelajaran IPS. Jakarta: Bumi Aksara
Isjoni. 2010. Cooperative Learning Mengembangkan Kemampuan Belajar Kelompok. Bandung: Alfabeta

Maya Kartika Sari. 2012. Pengenalan dan Pembelajaran IPS suatu Kajian Konsep Dasar IPS SD. Madiun : IKIP PGRI Madiun.

Sugiyono. 2007. Metode Penelitian Kuantitatif, Kualitatif dan $R \& D$. Bandung: Alfabeta

Suharsimi Arikunto. 2010. Prosedur Penelitian Suatu Pendekatan Praktik. Jakarta: Rineka Cipta

Maya Kartika. 2014. Pengaruh Metode Kooperatif Jigsaw Terhadap Prestasi Belajar Mata Pelajaran IPS Pada Siswa Kelas III di SD Islamiyah Pakualaman. Premiere Educandum Jurnal Pendidikan Dasar dan Pembelajaran/Volume 4/Nomor 2/Desember 2014

Trustho Raharjo. 2013. Pengembangan Media Pembelajaran Fisika Menggunakan Permainan Ular Tangga Ditinjau Dari Motivasi Belajar Siswa Kelas Viii Materi Gaya. Jurnal Pendidikan Fisika (2013) Vol.1 No.1 halaman 18. ISSN. $2338-0691$.

Rahina Nugrahani. (2007). Media Pembelajaran Berbasis Visual Berbentuk Permainan Ular Tangga untuk Meningkatkan Kualitas Belajar Mengajar di Sekolah Dasar. Jurnal Kependidikan jilid 36, No. 1 
